\title{
Indus Basin Waters A Main Resource of Water in Pakistan: An Analytical Approach
}

\author{
MUHAMMAD TAYYAB SOHAIL', HUANG DELIN ${ }^{1}$ and AQSA SIDDIQ ${ }^{2}$
}

\author{
${ }^{1}$ School of Public Administration, China University of Geosciences, \\ Wuhan 388 Lumo Lu, Wuhan 430074, Hubei, Province, China PRC. \\ ${ }^{2}$ School of Environmental Studies, China University of Geosciences, \\ Wuhan 388 Lumo Lu, Wuhan 430074, Hubei, Province, China PRC
}

http://dx.doi.org/10.12944/CWE.9.3.16

(Received: October 28, 2014; Accepted: December 02, 2014)

\begin{abstract}
The agriculture annulus in Pakistan aid $21 \%$ towards GDP of the country with mainly agriculture based economy. This ambit represents $45 \%$ of the country's labor force. Rivers are the main essence of water in Pakistan. This accounts for agriculture, commercial and domestic use. The veer in the availability of water of Rivers not only affects the economy but also the climate of the country. Water of these Rivers, directly or indirectly affects the lives of people in Pakistan. Indus River is the radical river which flows through the whole country until the brink of Arabian Sea. Indus Basin commences via Tibet flow from Jammu and Kashmir (India) to Pakistan. This paper is a descriptive study of water flow in the three giant rivers of Pakistan and conspicuously illustrate the past flow history, present condition and unborn recognition of water resources in the realm. The historical scansion and the unborn prediction of the attainment of water in the kingdom along with its consequences on the economy is also the ingredient of this inquest. The fright of critical water shortage is utterly tedious for Pakistan so there is a heinous exigency of ingenuous endeavors from the governance bodies to cope with these challenges. Notions to address this issue are also presented in this paper.
\end{abstract}

Key word: Indus basin, Pakistan, Agriculture, Environment, Economics

\section{INTRODUCTION}

Pakistan is prolific and hunky-dory when accounts for agricultural acclimation due to adequate modus operandi. Apropos irrigation and cultivation perspective, 22Mha out of $80 \mathrm{Mha}$ is devoted for agricultural purposes. Amidst assertion and speculations, cultivation region accrue over last three decades as the harvesting region flourished from 16.62Mha to 22.15Mha since 1971 to 2003 but due to explicit increment in population, per capita land availability has been descended ${ }^{1}$. It is quite exhilarating and deemed to be meritorious because agricultural economy is prospering day by day. But there's a catch, Pakistan is confronting problems that needs to be fully entertained for the continuous augmentation of economy. Categorically Indus River regarded as gigantic and proficient tool whilst improvising and assessing the agricultural system because it bears $90 \%$ of the water in aiding and acclaiming towards agriculture of Pakistan. Likewise other countries, amass population as per decade is vastly increasing in Pakistan and as per contemplations in relevance to projected estimation; the population will rise to 250 Million by 2025 which will ultimately eradicate the per capita availability of water ${ }^{2}$.

Indeed, Water is deemed as one of the essential requirements of life so assessing and improvising the usage of water is of supreme importance. Water usage can be categorized in three ways i.e. domestically, commercially and not but the least for land irrigation. Verily water is considered mandatory for the benevolence of ecology and for the well-being of ecological system. 
Natural and artificial are the radical resources of water in Pakistan as the natural abetments are rain, rivers, glaciers, ponds, lakes, streams and wells whilst the artificial sources are in the form of dams, reservoirs and stored water which attributes towards irrigation when needed to nullify the inadequate natural resources especially rain which would be complacent for the twofold benefits i.e. daily consumption cum hydroelectric power generation.

Agriculture is the one of the deference medium of income in Pakistan which is stimulating $21 \%$ contribution to the National GDP and accumulating $45 \%$ labor force to the country population depends on agriculture for their living ${ }^{3,4}$. To fulfill the quest of water to the fields, Pakistan depends vividly on the main source of water in Pakistan called Indus Basin.

Infelicitously Pakistan does not have vast resources to store the water like some other arid countries as United State of America and Australia having 5000 cubic meters, China has 2200 cubic meters and Pakistan merely has 1500 cubic meter of water stored as per capita. Agriculture robust Pakistan tacitly just likes thereabout countries of the region because most part of the population depends emphatically on agriculture in pursuit of prospering and nurturing life.

Water demand has been increasing due to its vast use in our daily life and it is an indispensable in our life. Normally the sources of water in the world are stream, rivers, lakes, rain water, Ponds and underground water ${ }^{5}$. As a whole, Water is not only important for daily necessities but it also translates into economic development. Water as a source having supreme accountancy and indomitable spirit for which there is no parallel. As water demands mammoth surplus supply, with emulous tasks from economic sector, and supremacist states, had led towards competitive, emulative, combat and chaos circumstances ${ }^{6}$. As Peter Gleick narrates, "it is inevitable to perish one factor which will always remain stationary: the culmination of water to life illustrates that it would be impossible to elude politics whilst anticipating water needs and fulfillments"'.
In 2011, 176.75 million people were dwelling in Pakistan and $64 \%$ of those were the whereabouts of rural areas ${ }^{8}$. Development of agriculture would descend inflation and poverty in Pakistan which would ultimately nourish economy. Annual rainfall in Pakistan is $494 \mathrm{~mm}$ whilst the renewable water resources are $230.8 \mathrm{~km} 3$ annually. The per capita annual water resources are $1,305 \mathrm{~km}^{9}$. Area of Pakistan is $796,100 \mathrm{~km} 2$, around $203,470 \mathrm{~km} 2$ or 26 percent is arable due to bizarre reasons. The land used for irrigation, cultivation and harvesting is $262,000 \mathrm{~km} 2$ or 33 percent of the total land ${ }^{8}$ Table-1.

\section{Data Analyses Methodology Selection of Rivers and Barrages}

The three main rivers of Pakistan have been selected in this study. Further in these three rivers we chosen three barrages named Chashma barrage on Indus, Rasul on Jhelum and Qadirabad on Chenab River (Fig 1).

\section{Data Collection}

In this research two kinds of data has been analyzed and discussed, first some online reports and survey has been discussed which showed the adverse picture of water resources, its uses and storage of water. Secondly some kinds of analyses have been included in the research on the base of some statistic data provided by Irrigation and Water treaty department of Pakistan. These departments had the record of daily base water flow of all the river of Pakistan. Some kind of results has been taken from that data, which covered the twenty three years of water flow from 1991-2013. Some kind of statistics has been applied to the monthly and annually flow of water. Monthly and annually flow has been discussed with the help of graphs statistical data information.

\section{Indus Basin and Agriculture of Pakistan}

A survey was conducted in 2011-12 on Pakistan's economy which revealed that agricultural economy counts heavily on the river water emerging from glaciers. The conducted survey comply aptly that the availability of water during 2011-12 for duo Kharif and Rabi crops were $10 \%$ and $19.2 \%$ short of normal rate contingently. Moreover, water for Rabi crop was surpassingly $15 \%$ less as compare to $2010-11$. (See Table 1). Karakoram-Hindukush-Himalaya ranges 
known as one of the largest reserves of glaciers comprising Pakistan surfing crystal clear water to the Indus River System, exclusively the World's largest irrigation system ${ }^{12}$. But this supply has been affected due to climate change since previous decades.

Because global temperature is rising, the glaciers are

Table.1: Pakistan and Agriculture

\begin{tabular}{lccccc}
\hline Country & $\begin{array}{c}\text { Agriculture } \\
\text { Contribution To GDP }\end{array}$ & $\begin{array}{c}\text { Rural } \\
\text { Population }\end{array}$ & $\begin{array}{c}\text { Labor Force } \\
\text { Employed In Agriculture }\end{array}$ & $\begin{array}{c}\text { Agricultural } \\
\text { Area }\end{array}$ & $\begin{array}{c}\text { Irrigated } \\
\text { Area }\end{array}$ \\
\hline Pakistan & $21.2 \%$ & $64 \%$ & $45.0 \%$ & $33 \%$ & $25.0 \%$ \\
\hline
\end{tabular}

Sources: FAOSTAT, 20118; ADB, 2011 ${ }^{10}$; and World Bank, $2011^{11}$

Table. 2: Actual Surface Water Availability

\begin{tabular}{lcccc}
\hline Period & $\begin{array}{c}\text { Kharif } \\
\text { (MAF) }\end{array}$ & $\begin{array}{c}\text { Rabi } \\
\text { (MAF) }\end{array}$ & $\begin{array}{c}\text { Total } \\
\text { (MAF) }\end{array}$ & $\begin{array}{c}\text { Increase/Decrease } \\
\text { (\%)Over the average }\end{array}$ \\
\hline $\begin{array}{l}\text { Average } \\
\text { System Used }\end{array}$ & 67.1 & 36.4 & 103.5 & - \\
$2003-04$ & 65.9 & 31.5 & 97.5 & -5.9 \\
$2004-05$ & 59.1 & 23.1 & 82.2 & -20.6 \\
$2005-06$ & 70.8 & 30.1 & 100.9 & -2.5 \\
$2006-07$ & 63.1 & 31.2 & 94.3 & -8.9 \\
$2007-08$ & 70.8 & 27.9 & 98.7 & -4.6 \\
$2008-09$ & 66.9 & 24.9 & 91.8 & -11.3 \\
$2009-10$ & 67.3 & 25.0 & 92.3 & -10.8 \\
$2010-11$ & 53.4 & 34.6 & 88.0 & -15.0 \\
$2011-12$ & 60.4 & 29.4 & 89.8 & -13.4 \\
\hline
\end{tabular}

Note: MAF- million acre feet;

Source: Indus River system Authority, Economics Survey of Pakistan 2011-123

Table 3: Future Water Requirement

\begin{tabular}{|c|c|c|c|c|}
\hline $\begin{array}{l}\text { Sr. } \\
\text { no }\end{array}$ & Description & Year 2000 & Year 2025 & $\begin{array}{c}\text { Additional Water } \\
\text { Requirement (MAF) }\end{array}$ \\
\hline \multirow[t]{2}{*}{ A } & Population (Million) & 131.51 & 208.66 & \\
\hline & & $\begin{array}{l}\text { Existing Uses } \\
\text { (MAF) }\end{array}$ & $\begin{array}{l}\text { Requirement } \\
\text { (MAF) }\end{array}$ & \\
\hline \multirow[t]{5}{*}{ B } & Non-Agricultural Sector & & & \\
\hline & Water Supply and Sanitation & 4.5 & 10.5 & 6.0 \\
\hline & Industry & 2.2 & 3.5 & 1.3 \\
\hline & Environmental Protection & 1.3 & 1.7 & 0.4 \\
\hline & Total & 8.0 & 15.7 & 7.7 \\
\hline \multirow[t]{2}{*}{ C } & Agriculture Sector Requirement & & & \\
\hline & At Canal Heads & 105.0 & 142.0 & 37.0 \\
\hline D & Total $(B+C)$ & 113.0 & 157.7 & 44.7 \\
\hline
\end{tabular}

Source: GOP, $2004^{14}$ 


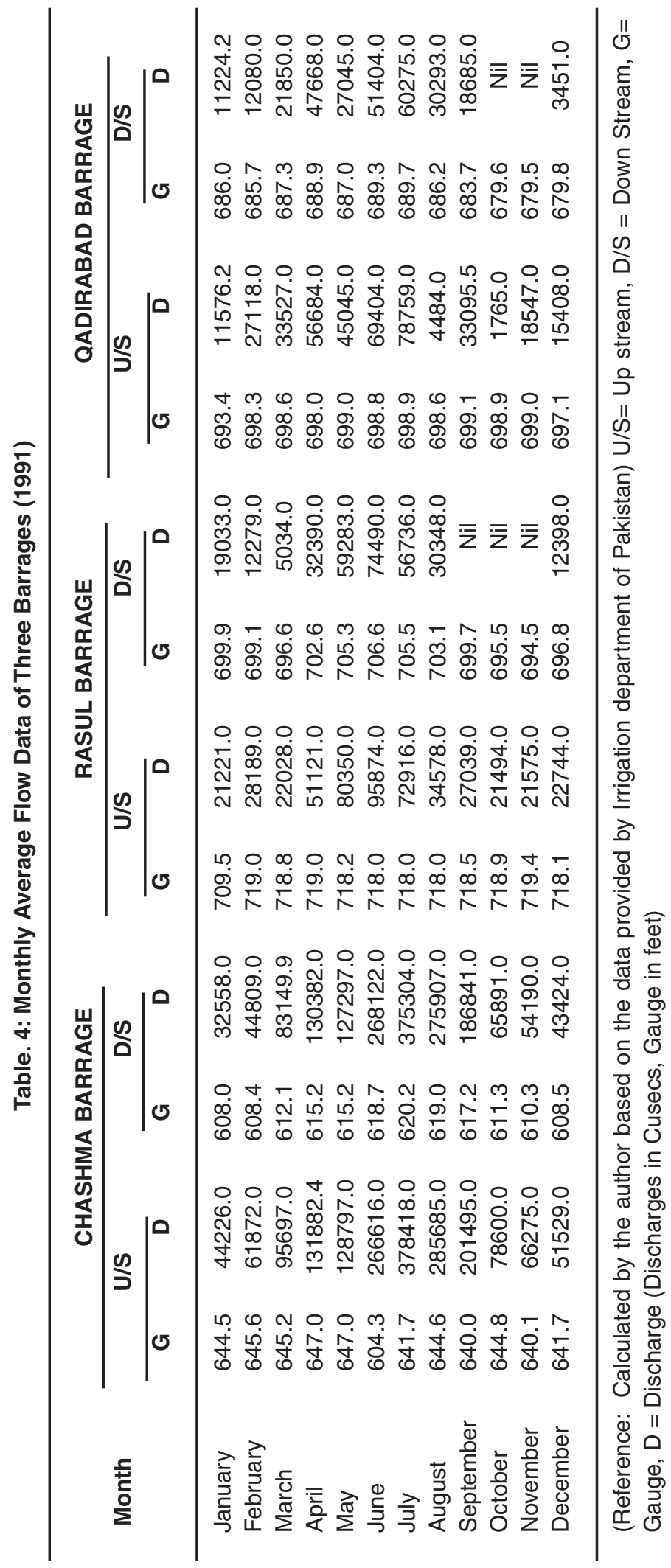


melting at alarming rate. Climatologists believed that global warming will result strengthening, rushing or heightening of the global hydrological cycle. There is also some evidence about it in the world and also in Pakistan because Pakistan also faced floods every year. There is evidence that the global climate is varying and some of the change is human-induced. The main impact of climate variation on human and the environment happens through water.

In the same survey (2011-12) it complies that the Integrated Irrigation Network of Indus Basin is under severe threat due to water logging and hydro-salinity which would dent adverse effects on pollution along with contamination of surface and ground water. Therefore, it is imperative and impulsive to consign an inclusive environmental management plan and procedure for approval and implementation to take place ${ }^{13}$

\section{Analytical Approach}

Water is a vital element for the existence of living things. It is epic factor for economic development and for enlarging growth of agriculture and industry. Pakistan is a developing country making development in every field of life. But unfortunately in the field of water management there is not a satisfactory attitude from the responsible authorities. As we know we are losing our water resources day by day with increasing rate of population. In 2000 the population of Pakistan was 131.51 million and we had the water resources in non-Agriculture sector 4.5 (MAF) and for agriculture sector 105.0 (MAF) but in 2025 the expected population will be 208.66 million with the water requirement in non-Agricultural 10.5 (MAF) and for agriculture 142.0 (MAF) (Table-3). It means Pakistan need 44.7 (MAF) water extra to cop up the situation in 2025. But if we see the current situation of water resources in Pakistan, it's seemed they will not fulfill the requirement of the country. The remaining glacier also melting due to the global warming and Pakistan does not have the sufficient capacity to storage water. Due to this problem Pakistan is also facing a huge level of load shedding in the country. So dams and water storage are demand of present time to save the

Table. 5: Historical Flood Events Experienced In Pakistan

\begin{tabular}{cccccc}
\hline Sr. No & Year & $\begin{array}{c}\text { Direct losses } \\
\text { (US\$ million) }\end{array}$ & $\begin{array}{c}\text { Lost lives } \\
\text { (No) }\end{array}$ & $\begin{array}{c}\text { Affected } \\
\text { villages (No) }\end{array}$ & $\begin{array}{c}\text { Flooded area } \\
\text { (Sq-km) }\end{array}$ \\
\hline 1 & 1950 & 488 & 2,190 & 10,000 & 17,920 \\
2 & 1955 & 378 & 679 & 6,945 & 20,480 \\
3 & 1956 & 318 & 160 & 11,609 & 74,406 \\
4 & 1957 & 301 & 83 & 4,498 & 16,003 \\
5 & 1959 & 234 & 88 & 3,902 & 10,424 \\
6 & 1973 & 5134 & 474 & 9,719 & 41,472 \\
7 & 1975 & 684 & 126 & 8,628 & 34,931 \\
8 & 1976 & 3485 & 425 & 18,390 & 81,920 \\
9 & 1977 & 338 & 848 & 2,185 & 4,657 \\
10 & 1978 & 2227 & 393 & 9,199 & 30,597 \\
11 & 1981 & 299 & 82 & 2,071 & 4,191 \\
12 & 1983 & 135 & 39 & 643 & 1,882 \\
13 & 1984 & 75 & 42 & 251 & 1,093 \\
14 & 1988 & 858 & 508 & 100 & 6,144 \\
15 & 1992 & 3010 & 1,008 & 13,208 & 38,758 \\
16 & 1994 & 843 & 431 & 1,622 & 5,568 \\
17 & 1995 & 376 & 591 & 6,852 & 16,686 \\
18 & 2010 & 10,000 & 1,985 & 17,553 & 160,000 \\
19 & 2011 & 3730 & 516 & 38,700 & 27,581 \\
20 & 2012 & 2640 & 571 & 14,159 & 4,746 \\
\hline & & & & & \\
\hline
\end{tabular}

Sources: Government Of Pakistan (2013), Annual flood report ${ }^{17}$ 
country. These are elements which also leave direct impact on the economy of a country, especially an agricultural country like Pakistan. Verily, Pakistan is one of the water stressed countries in the world; the current situation is conducive for the shortage of water availability because of the high population growth rate. If we see the history of water availability

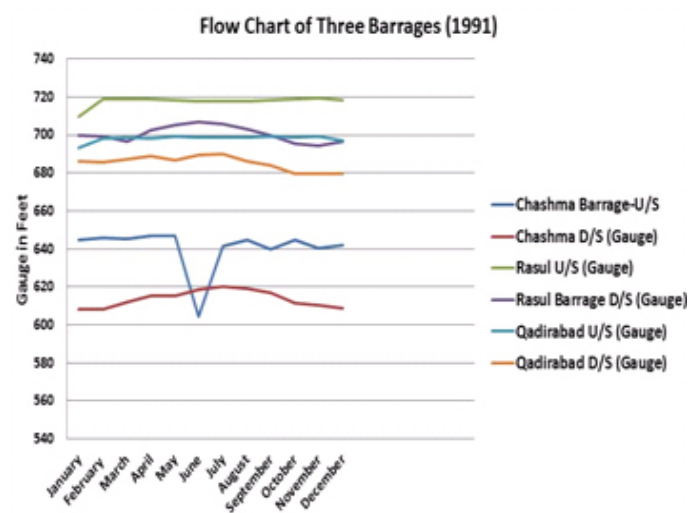

Fig. 2: Flow Chat of three Barrages

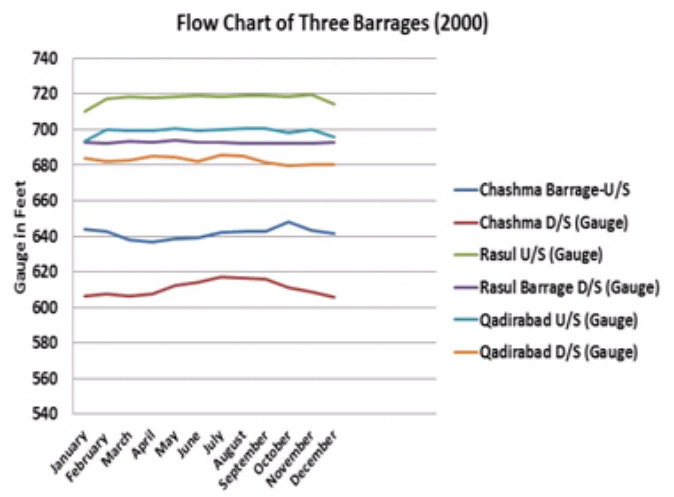

Fig. 4: Flow Chat of three Barrages

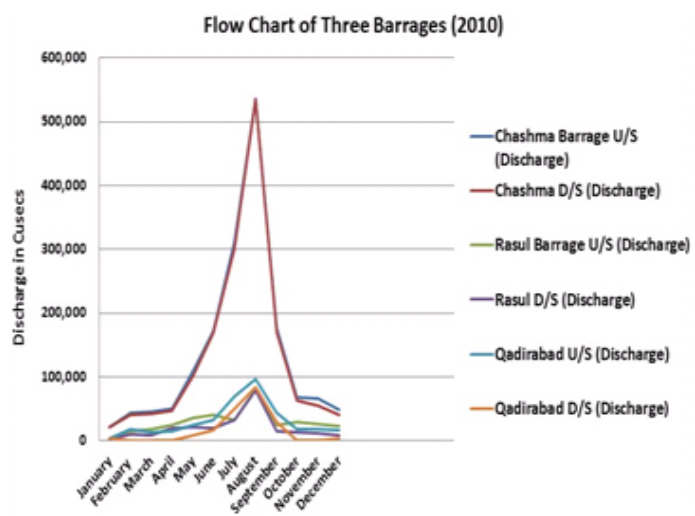

Fig. 6: Flow Chat of three Barrages for crops from 2003-2012, we will see in the whole time period, the water availability was low as per demand (Table-2).

According to 1998 census, 132 million was the population of Pakistan, which would surpass 209 million by 2025 at a growth rate of $1.5 \%$ annually.

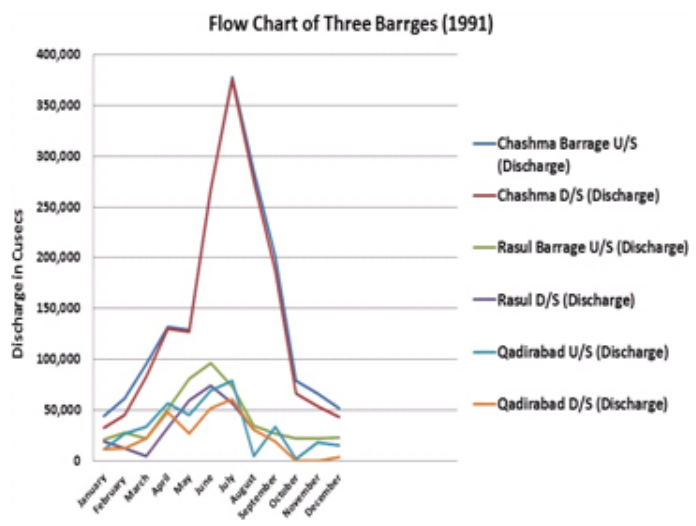

Fig. 3: Flow Chat of three Barrages

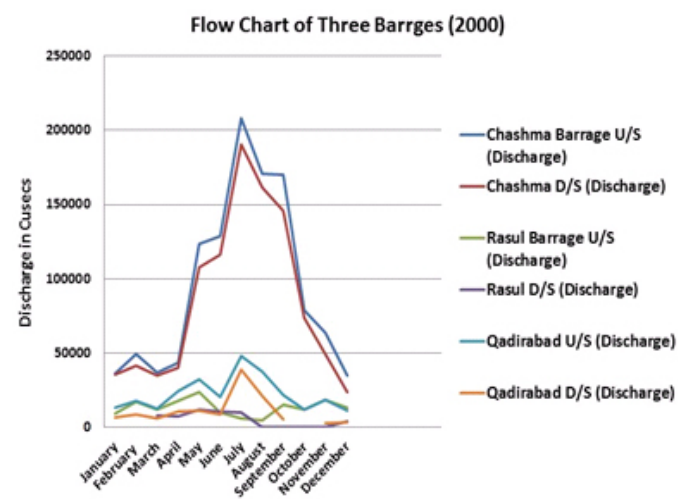

Fig. 5: Flow Chat of three Barrages

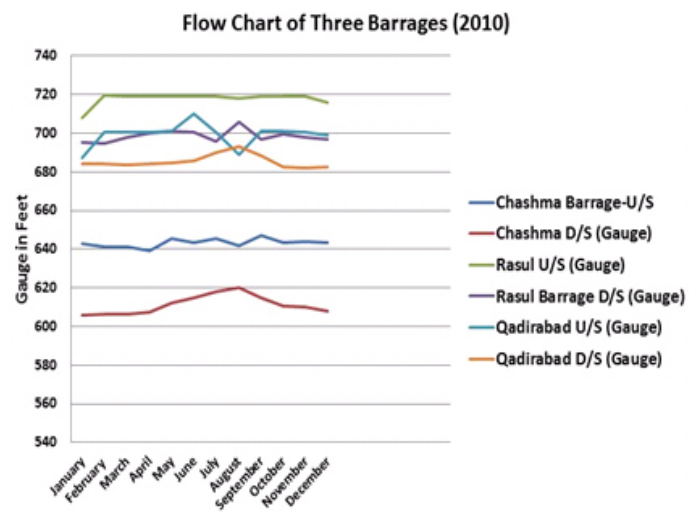

Fig. 7: Flow Chat of three Barrages 


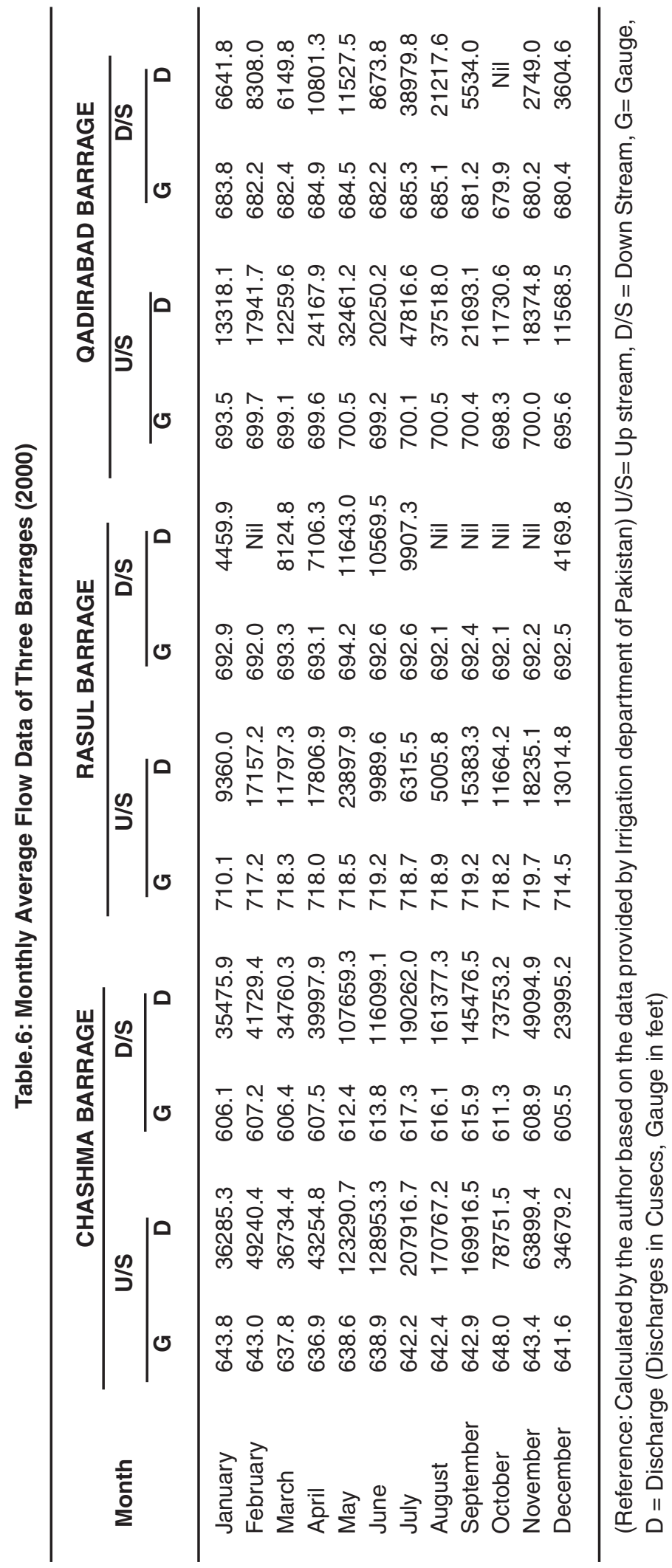




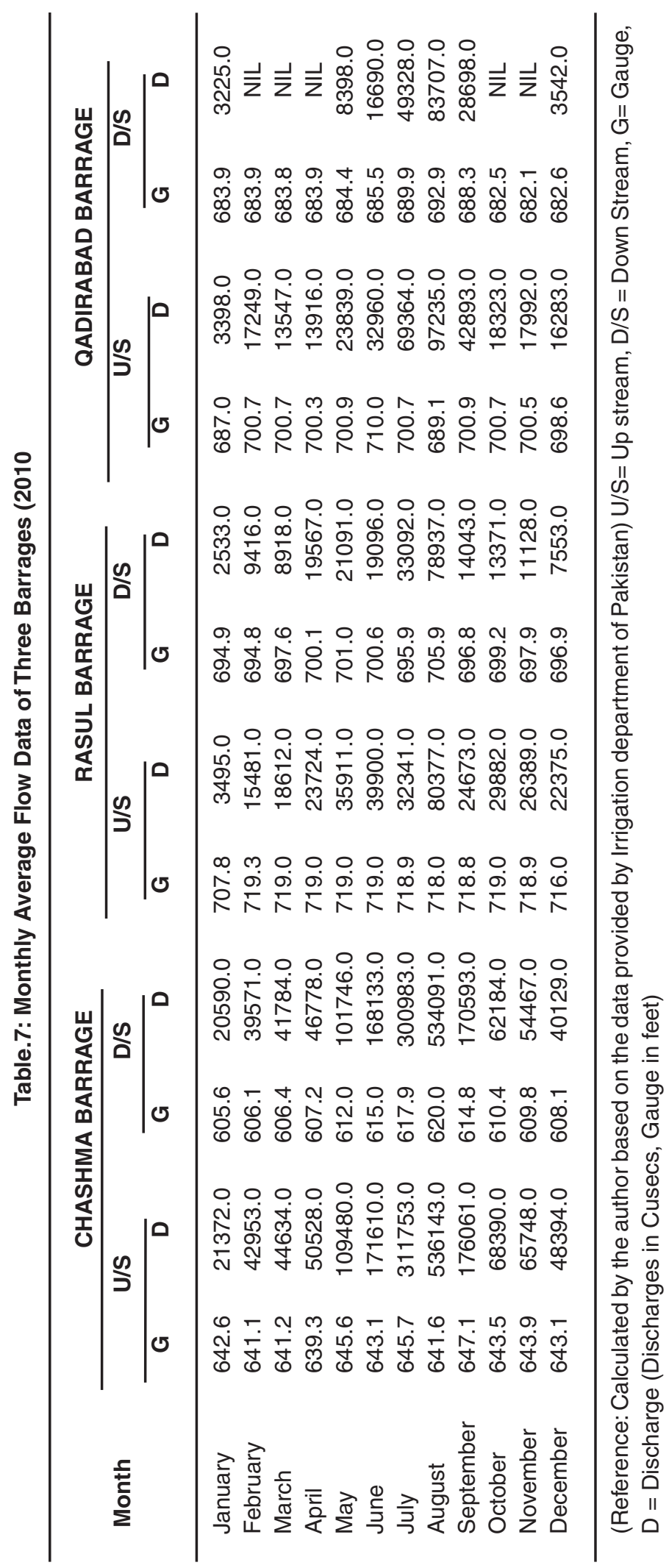




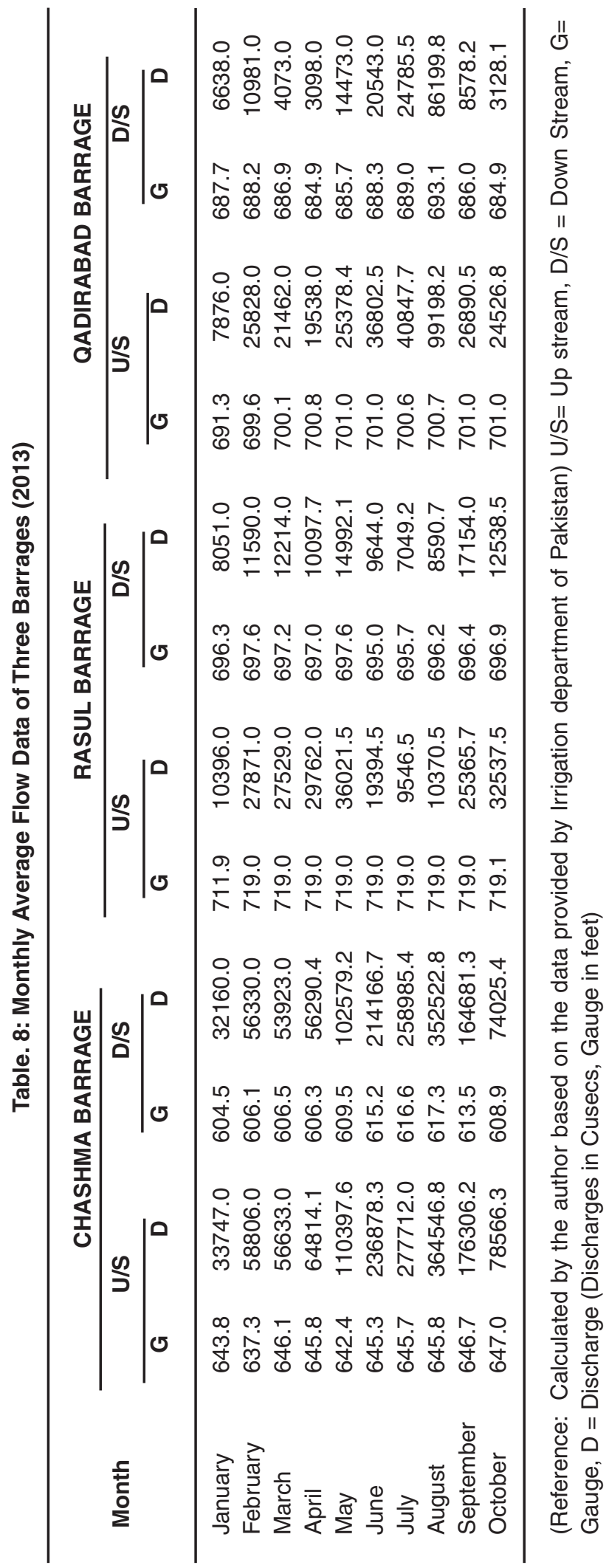




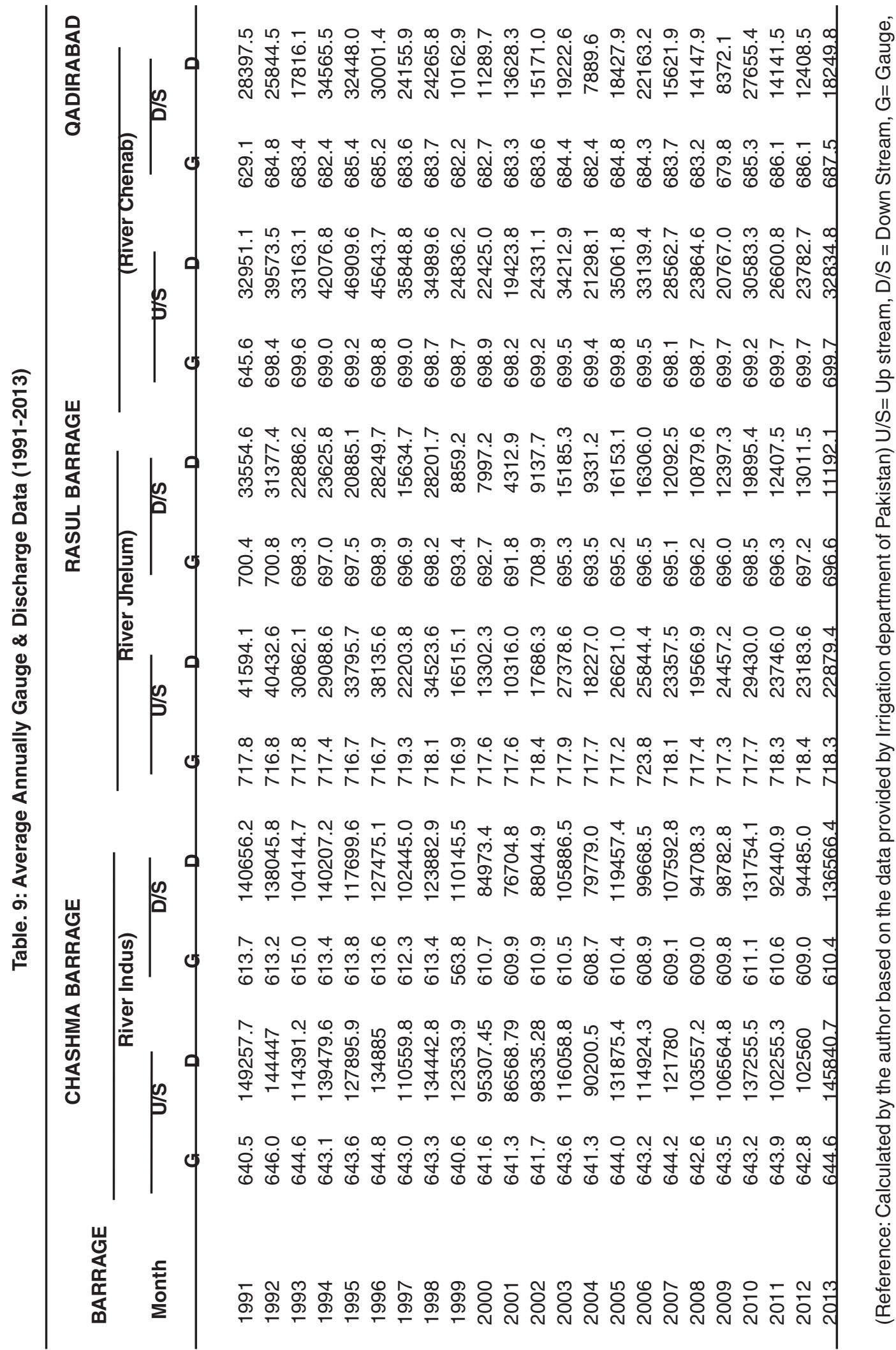


Taking this fact into consider Pakistan should accrue the availability of water to $23 \%$ to fulfill the requirement of population until 2025. At the same time demand of water for agriculture will be 101.7 and 125.3 MAF for 2010 and 2025, considerably $19 \%$ increment for the water requirements in agriculture. To meet this demand can raise the issue of water between the provinces and also with the neighboring country which are using water from Indus basin.

The Pakistan Economic Survey 2010-11, firmly addressees that water related matters are premier threats in Pakistan. It narrates, 'the current water resources in Pakistan are appalling and unsecured due to apathy and dismantling of filthy

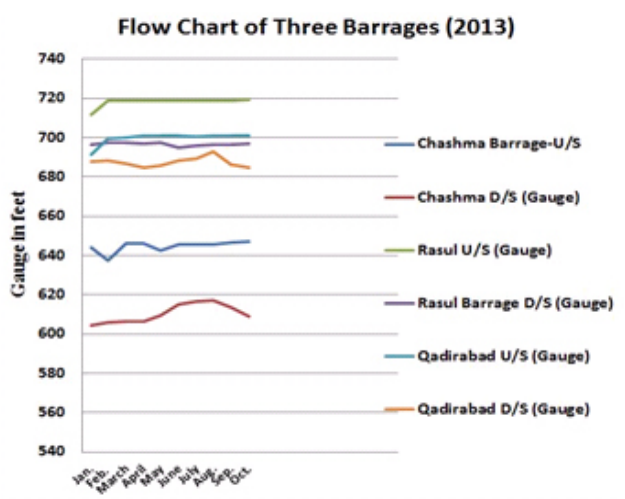

Fig. 8: Flow Chat of three Barrages discharge of industrial beverages and poisonous chemicals into rivers and other bodies in the shape of surface water. Haplessly, Most of the people drinking impure, maculate and nasty water which explicitly refer the mismanagement of water policies in Pakistan. Water contamination is a global issue especially in developing countries is alarming and the reason may be the poor management ${ }^{15}$. Drinking of polluted water can result various serious health problems ${ }^{16}$.

Basic Statistical Characteristics on monthly and Annual Stream flow Discharge

On the base of stream flow data over the period 1991-2013 from the three rivers of Pakistan,

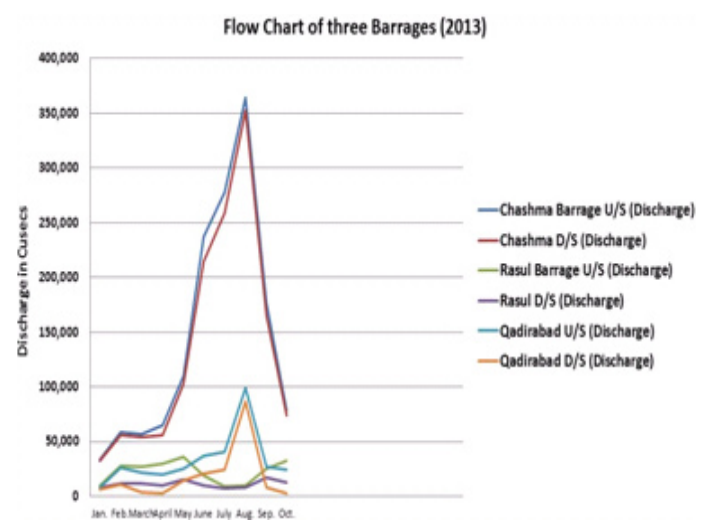

Fig. 9: Flow Chat of three Barrages

\section{CHASHMA BARRAGE}

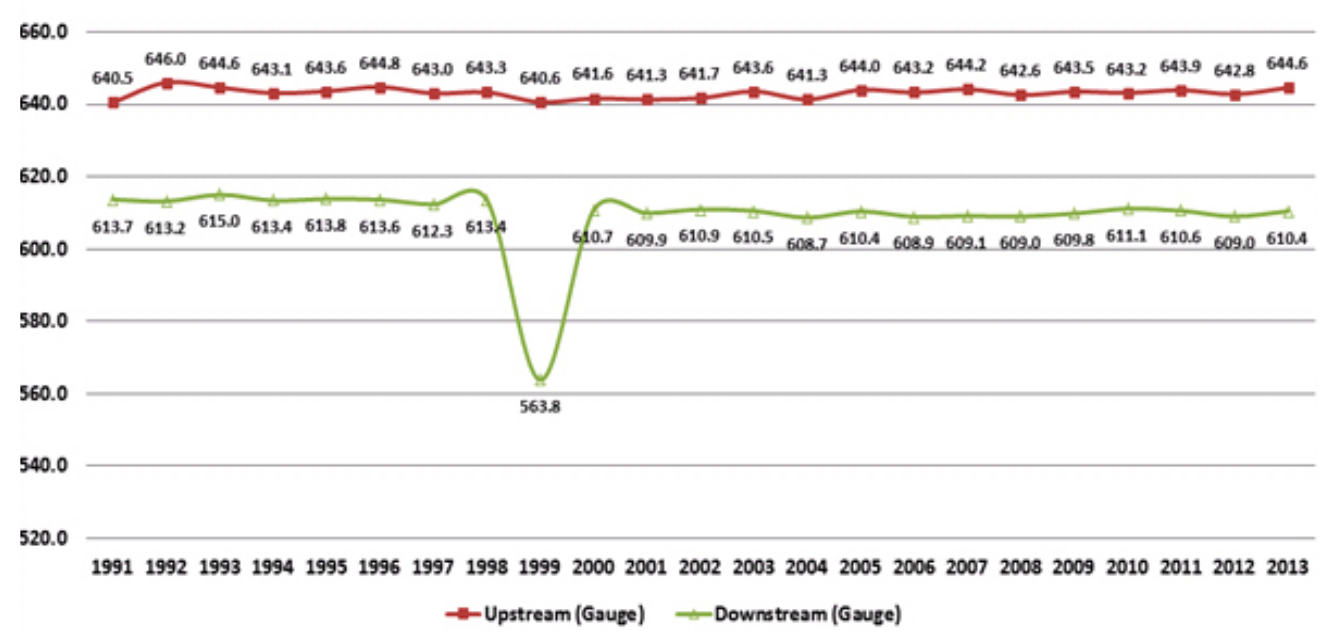

Fig. 10: (Reference: Draw by the author based on the data provided by Irrigation department of Pakistan) U/S= Up stream, D/S = Down Stream, G= Gauge, D = Discharge (Discharges in Cusecs, Gauge in feet) 
the following characteristics on the stream flow were analyses.

1) The average monthly and annually flow over the period 1991-2013 from the three main rivers of Pakistan.

2) Ups and down in water has been discussed.

3) Reasons of floods and management lack.

\section{RESULTS AND DISCUSSION}

As discussed earlier Pakistan is a mainly agriculture country and a main part of the country depend on river water for their fields. But the river water is not only used for the agriculture purposes but also for the industry, domestic use. Underground water recharging also depends on the rivers water and rains. Pakistan has some other rivers too but

\section{CHASHMA BARRAGE}

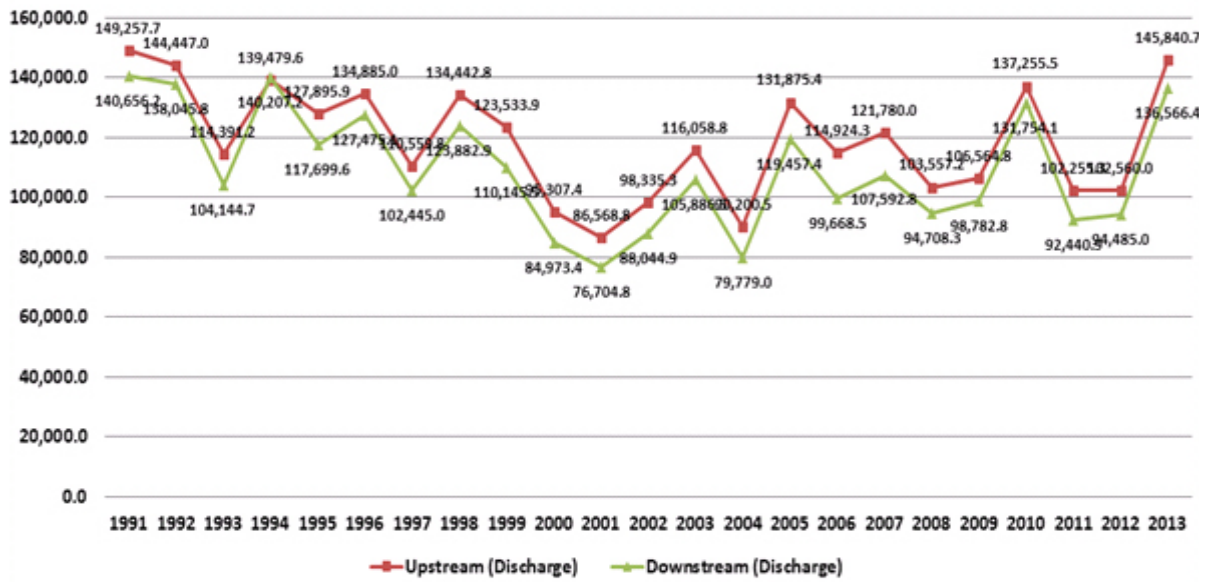

Fig. 11: (Reference: Draw by the author based on the data provided by Irrigation department of Pakistan) U/S= Up stream, D/S = Down Stream, G= Gauge, D = Discharge (Discharges in Cusecs, Gauge in feet)

\section{RASUL BARRAGE}

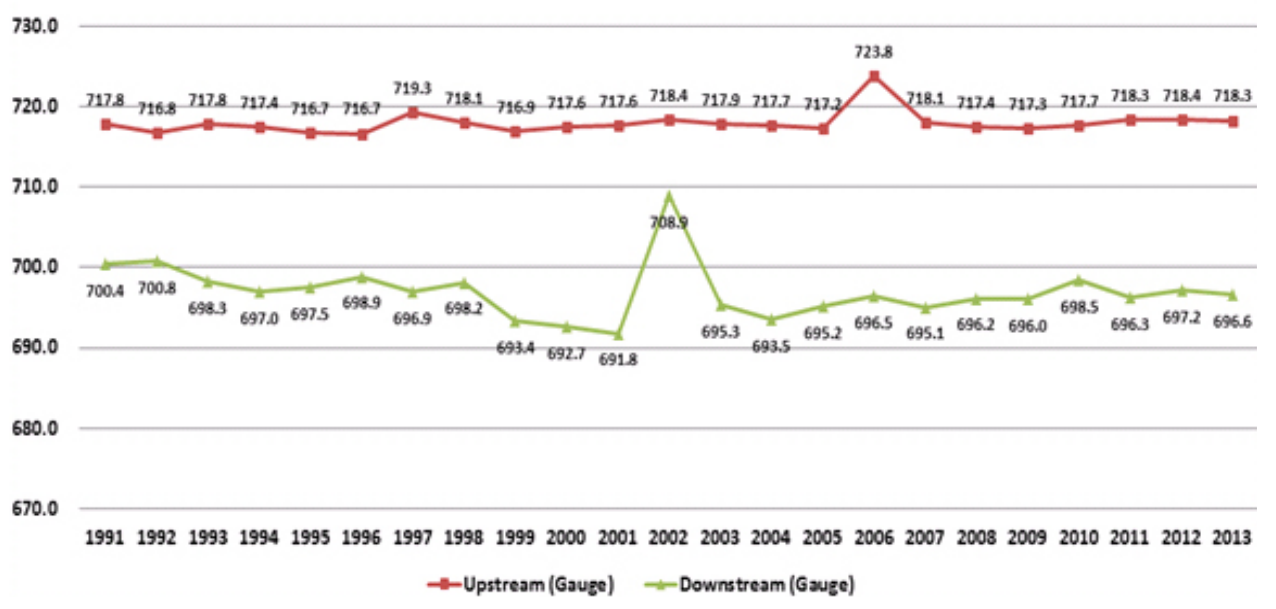

Fig. 12: (Reference: Draw by the author based on the data provided by Irrigation department of Pakistan) U/S= Up stream, D/S = Down Stream, G= Gauge, D = Discharge (Discharges in Cusecs, Gauge in feet) 
Indus River is the main river in Pakistan which flow through the whole country to Arabian Sea. In this research we had chosen three Barrages on the three rivers Chasma Barrage on Indus River, Rasul Barrage on Jhelum and Qadirabad Barrage on Chenab River of Pakistan. We used previous 23 years (1991-2013) water flow has been discussed with the help of Charts and graphs. $1^{\text {st }}$ of all we gave the picture of the barrages with ten year gap (19912000-2010, 2013) of water flow. In this research our mainly focus was on the discharge flow from the above mentioned barrages but to some extent gauges were also part of the research. Water discharge flow in the all barrages has been indicated up and down in the mentioned years, usually the flow rate remain high during April-May but higher during July-September. The discharge rate in the Indus River reached 375304 Cusecs in July, 1991, 207916.7 Cusecs in July, 2000, 536143 Cusecs in August 2010 and 364546 Cusecs in August 2013 (Table. 4,6,7,8 and Fig 3, 5, 7, 9). Usually during the highest flows in these rivers become destructive in

\section{RASUL BARRAGE}

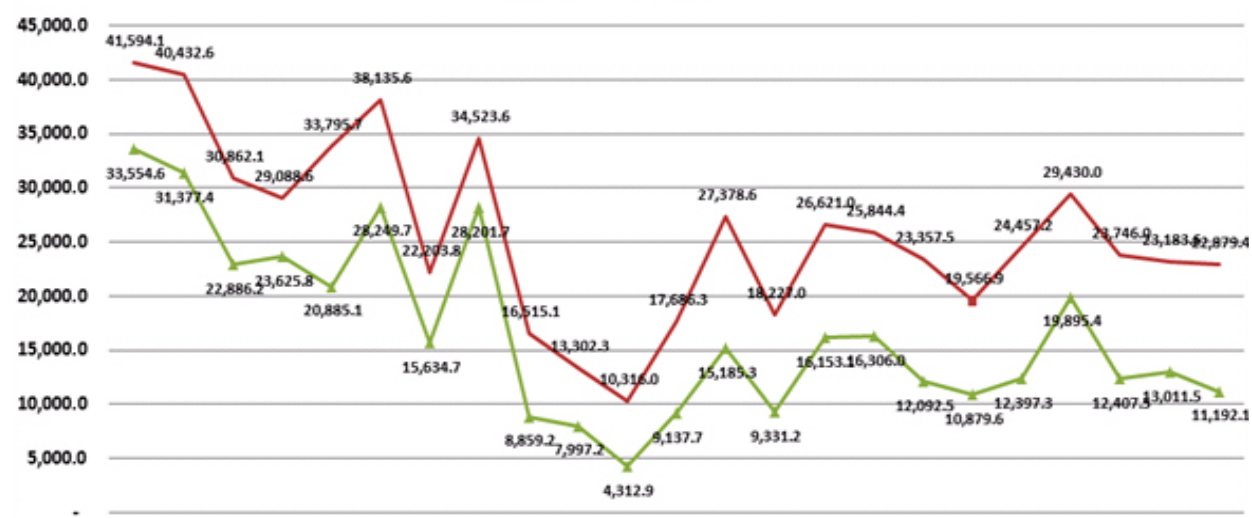

19911992199319941995199619971998199920002001200220032004200520062007200820092010201120122013

$$
\text { -Upstream (Discharge) -Downstream (Discharge) }
$$

Fig. 13: (Reference: Draw by the author based on the data provided by Irrigation department of Pakistan) U/S= Up stream, D/S = Down Stream, G= Gauge, D = Discharge (Discharges in Cusecs, Gauge in feet)

\section{QADIRABAD BARRAGE}

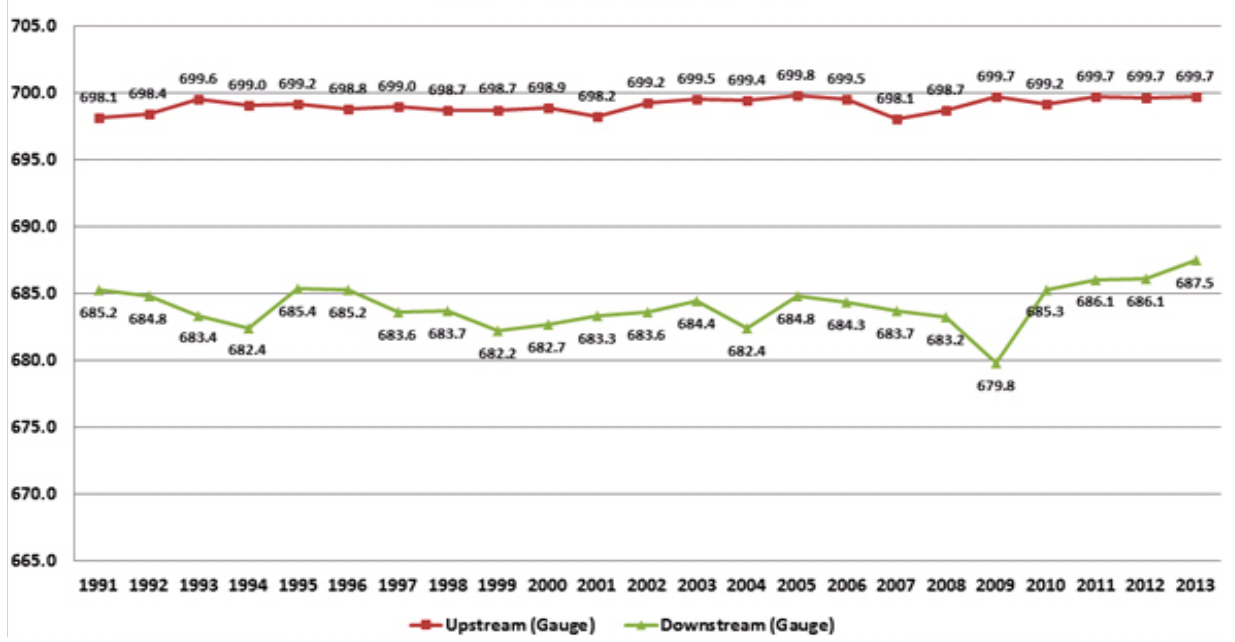

Fig. 14: (Reference: Draw by the author based on the data provided by Irrigation department of Pakistan) U/S= Up stream, D/S = Down Stream, G= Gauge, D = Discharge (Discharges in Cusecs, Gauge in feet) 
the shape of flooding which enter the nearby cities and villages, a lot of people lost their lives, properties, crops and animals, which presented the bad image of Government bodies in the water resources management (Table 5) because this highest flow was not one or two time. We can see this highest flow ratio in the 23 years history of water flow, but related government bodies never take it serious and did not make any permanent solution of this and people are losing their belonging and life still now

The Table represents the water flow rate of three barrages from 1991-2013. If we see the water flow history of chashma Barrage, we will see it is decreased during the year 2001-2004 but after that it become a little higher again in the coming years (Table, 9 Fig. 10, 11). But the situation in the other two rivers is adverse. It is decreasing every year the Rasul Barrage discharge rate was 33554.6 Cusecs in 1991 but now in 2012 it was 13011.5 Cusecs, which is less than half of 1991, Qadirabad Barrage also have the same situation it was 28397.5 Cusecs in 1991 but in 2012 it was 12408.0 which is also less than half of 1991 (Table 9, Fig, 12, 13, 14, 15). This decrease in water resources of these rivers are questionable and need a serious attention from the concerned authorities of Pakistan. If the water ratio will continuously decrease it will not only affect the economy of Pakistan, but also will leave direct effect on the lives of people.

\section{CONCLUSIONS}

As discussed earlier, agriculture is the backbone of Pakistan and water flow in the country is like a blood moving in its veins. If there is water scarcity then its mean we will face it in the economic and social threats. Lesser amount of water bow less agricultural crops. Corollary, we will be defective and deficient craving for food requirements and dependent on other countries. May be Pakistan will need to import a lot of things including daily use food stuff. Rivers are not only providing water to yields, it's also a source of underground earth water recharge along with rain. So in future there will be no water and consequently it will increase the load on underground water. Latterly, dependence on ground water for irrigation will utterly bring the water table down and causing formidable water influence for population. Diminutive agricultural attainments will compel mob to migrate towards urbanization in pursue of job, labor work causing increment in inflation and unemployment enhancing burdensome on economy and environment by contaminating water effectively.

The paper scansion various genre relating water resources of Pakistan and accomplish water management approach. One should always hold the belief that water related affair are supremacist whilst negotiating economic development and progress of

\section{QADIRABAD BARRAGE}

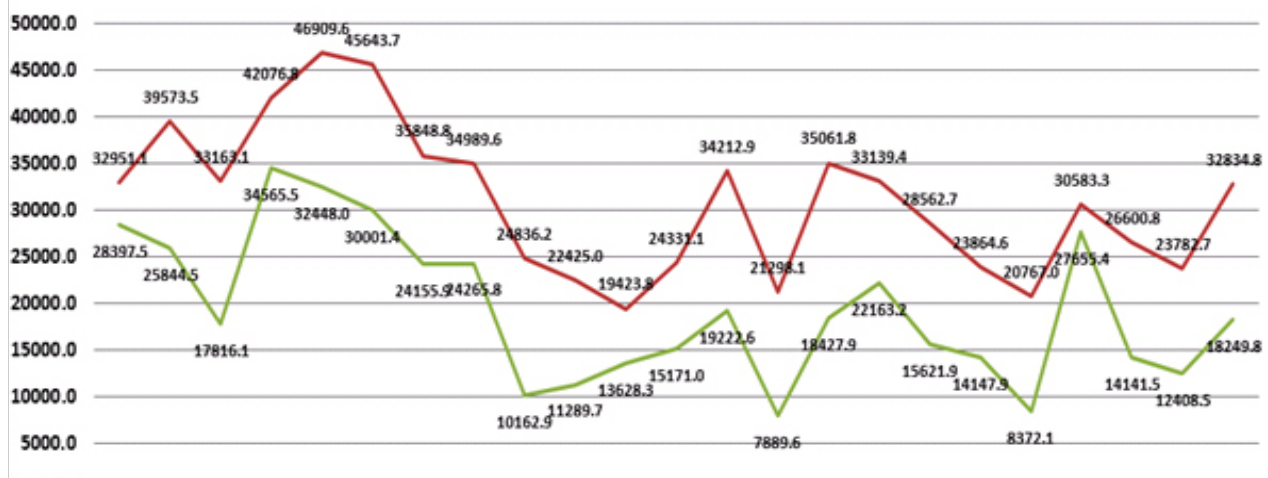

19911992199319941995199619971998199920002001200220032004200520062007200820092010201120122013

— Upstream (Discharge) —Downstream (Discharge)

Fig. 15: (Reference: Draw by the author based on the data provided by Irrigation department of Pakistan) U/S= Up stream, D/S = Down Stream, G= Gauge, D = Discharge (Discharges in Cusecs, Gauge in feet) 
Pakistan. Gallop growing of population and enhanced applications of water utterly causing adverse affects. Adversely the water sources are not adjoining with usage and demands of water. Global warming is another challenge. Since its glaciers are melting at very high pace, so every year we face floods and as deprecation we get huge and unrepeatable loses i.e. human lives, belonging, capital, property of public and private sectors. Pakistan is facing flood every year, but unfortunately we cannot see some permanent solution in the country to saves the life and belonging of the affected area. Pakistan's waterresources have been falling down at an alarming rate, as can be determined from the above-stated facts. It is now water stressed country. The availability of water has descended from $1,299 \mathrm{~m}^{3}$ per capita in 1996-97 to $1,100 \mathrm{~m}^{3}$ per capita in 2006 and that of likely less than $700 \mathrm{~m}^{3}$ per capita by 2025 .

If we see Pakistan we will see there is a load shedding, there is flood and there is a lack of dams for to storage water. These all are interconnected with each, so we can say Pakistan has some resources, but there is a lack of management. Proper irrigation system in the whole country, dams for to storage water, productions of electricity are necessitates of present time. According to present study following suggestions can be carried out:

1. Shortfall of water in Pakistan demands a negotiation with the all bodies with whom Pakistan have a water issues national and at international level. At the same time management authorities also needs to solve the water issue which is between the provinces. Main authorities from government need to share all water resources equally for the smooth run of agriculture of the country and for the other requirement of water.

2. To overcome such threats diminutive dams at obligatory and incumbent places should be constructed, especially the areas which known a red zone for floods every year.

3. Pakistan needs a big dam for to store water and for the production of electricity, Kalabagh and Bhasha Dams can help to cop the present and future needs of Pakistan, so government should constitute a team to review the objections of Sindh and KPK provinces on this project for to find a solution to make this dam.

4. Government of Pakistanneeds to make policy in the aspect of two elements water development and management. The water development policy mainly composed of making new storage reservoirs whilst the water management invention will help in reducing the perennial losses. Moreover implementations of policies are more important.

5. Government should make some policies to store water at the local level, every district should have some reservoirs to store water, and rain water should be stored for household use and can be for agricultural use. All new housing societies should be established to meet these criteria that there would be some water storage plant to store domestic use water and to provide safe drinking water to the citizens of countries.

6. A proper sustainable management of water is necessary for the future of Pakistan.

\section{ACKNOWLEDGEMENTS}

I would like to shower my humbly gratitude's to China Government Scholarship council (CSC) Beijing, China and International Education College of China University of Geosciences, Wuhan, China for their valuable supports and openness that they had blessed me opportunities to do this work. I would also like to pay my attribute towards Irrigation and Indus Water Treaty department of Pakistan for to provide me data of water flow.

\section{REFERENCE}

1. Ahmad, K. F. Z., Muhammad, S., UL, H. M., Tahira, G. H., Feehan, H., Amir, M. S., \& Atif, W. Agricultural dynamics in pakistan: current issues and solutions. Russian Journal of Agricultural and Socio-Economic Sciences, 20(8) (2013).

2. Bhutta, M.N, 1999. Vision on Water for
Food and Agriculture: Pakistan Perspective: Regional South Asia Meeting on Water for Food and Rural Development, New Delhi, June 13, 1999.

3. 'Pakistan Economic Survey (2011-12), 237, http://cdn.onepakistan.com/content/2012/ budget/16-Environment.pdf (accessed 
August 20, 2012).

4. Ministry of Finance (2010). .Agriculture.. Economic Survey 2009 10. Ministry of Finance, Pakistan. Available at:http://www.finance.gov. pk/survey/chapter 10/02 Agriculture.pdf

5. Ajon, A.T., \& Utsev, J.T. (2014) Physicochemical Quality of Irrigation Water in River Katsina-Ala Catchment Areas of Northern Nigeria. Current World Environment,9(2), 301-311.

6. Sahni, Hamir K (2006). The Politics of Water in South Asia: The Case of the Indus Waters Treaty. The Johns Hopkins University Press. Volume 26, Number 2,, 153-165.

7. Gleick, P. H. (2004). The water conflict chronology. In The World's Water 20042005: The Biennial Report on Freshwater Resources. Gleick, P. H. (ed.). Island Press, Covelo, CA, pp. 234- 255

8. FAOSTAT, 2011. FAO Statistical Yearbook. 20 Dec 2011. <faostat.fao.org>

9. Asia Pacific Adaption Network (APAN). (February 2012). Technical report on Issues related to Water and Agriculture in South Asia. Pelawatta, Battaramulla Sri Lanka: Global Water Partnership South Asia (GWP SAS),.

10. ADB, 2011. Key Indicators for Asia and Pacific. Mandaluyong City, Philippines: Asian Development Bank. 10 Dec 2011. http://www.adb.org/Documents/Books/Key
Indicators/2011/pdf/Key-Indicators-2011.pdf

11. World Bank, 2011. Agriculture in South Asia. 15 Jan 2012. <http://web.worldbank. org/wbsite/external/countries/ southasiaext/ extsaregtopagri/>saarc. 2012.

12. Chestney, N. (2012). Global Warming Close to Becoming Irreversible: Scientific American. Scientific American.

13. Pakistan Environmental Protection Agency, Islamabad, Ministry of Climate Change as stated in Planning Commission of Pakistan's Annual Plan 2012-13.

14. Government of Pakistan, 2004. National water policy: National report on water resources of Pakistan, Available and requirement plansInception Brief. ADB consultant for Punjab irrigation and power department

15. Akhtar Malik Muhammad, T.Z. (2014). A Study to Investigate and Compare Groundwater Quality in Adjacent Areas. Nature Environment and Pollution Technology, 1-10.

16. Patil, v., \& Patil, p. (2006). Assessment of water quality of selected tube wells in amalner town of jalgaon district, maharashtra. parameters, 2007

17. Government of pakistan,(2013). Annual flood report 2013. Office of the chief engineering advisor/chairman, federal flood commission islamabad : ministry of water and power. 